African Journal of Educational Studies in Mathematics and Sciences Vol. 16, No. 2. 2021

\title{
Students' conceptual understanding of organic chemistry and classroom implications in the Rwandan perspectives: A literature review
}

\author{
A. Sibomana ${ }^{1}$ and C. Karegeya ${ }^{2}$ and J. Sentongo ${ }^{3}$
}

\begin{abstract}
Chemistry subject continues to be considered as difficult to teach and learn. This leads to students' low academic achievement, retention, and negative attitude towards the subject. Organic chemistry as one of the concepts on which technological advancement is constructed sometimes appears to be enormously complex to students. There are some persisting misconceptions about it although different innovative instructional strategies have been applied and this area is of main concern as the learning of students can be extremely hindered in case their misconceptions are not minimized and/or corrected. The review then is to equip educators with knowledge about organic chemistry concept and source of students 'misconceptions; the misconceptions of students about organic chemistry; the ways of diagnosing students' misconceptions and remedies of those misconceptions; some learning theories for the effective organic chemistry instruction and classroom implications. The paper is also useful to know more about the minimization of students' misconceptions and leading them to the great academic achievement and interest towards the subject by employing cooperative learning models; thus, many other different innovative teaching strategies are recommended to apply in organic chemistry instruction.
\end{abstract}

Keywords: Conceptual understanding, chemistry education, innovative teaching, misconceptions, organic chemistry

\section{Introduction}

Organic chemistry, the subdivision of chemistry that treaties with the structure, properties, and reactions of combinations that contain carbon, and these compounds are known as hydrocarbons since they contain both hydrogen and carbon atoms mainly. Organic chemistry has invaluable importance in the daily life of every people worldwide and has many unforeseen potential benefits for our future due to its role of being applied in different manufactures (Roy, 2016). It is the building block for all living organisms, though many studies view it as the topic that trusts deeply on memory and recall (Omwirhiren \& Ubanwa, 2016). Organic chemistry is also the chemistry of carbon mixtures, excluding

\footnotetext{
${ }^{1}$ Aimable SIBOMANA is doctoral student at the African Center of Excellence for Innovative Teaching and Learning Mathematics and Science (ACEITLMS), University of Rwanda, College of Education; Rukara Campus; P.O. Box. 55 Rwamagana, Kayonza, Republic of Rwanda. Email: aimablehorasibomana@gmail.com

${ }^{2}$ Claude KAREGEYA, University of Rwanda, College of Education (UR-CE); Department of Mathematics, Science and Physical Education, Rwanda. Email: aimablehorasibomana@gmail.com

3John Sentongo, Makerere University, College of Education and External Studies, Department of Science, Technical and Vocational Education (DSTVE), Kampala- Uganda
}

Open Access article distributed under the terms of the Creative Commons Attributions License [CC BY-NC-ND 4.0] http://creativecommons.org/licenses/by-nc-nd/4.0. DOI: https://dx.doi.org/10.4314/ajesms.v16i.2.2 
Students' conceptual understanding of organic chemistry and classroom implications in the Rwandan perspectives: A literature review

A. Sibomana and C. Karegeya and J. Sentongo

carbon oxides, metal carbonyls, metallic carbonates, and other related compounds (Mahaffy, 2004). It is also known as the chemistry of hydrocarbon and its derivatives (Omwirhiren \& Ubanwa, 2016).

Scholars grow and improve numerous ideas and conceptions about everything they receive from the milieu and do not arrive the classrooms as the blank vessel, but they arrive with prior information or ideas of concepts in science that will be developed/oriented by the classroom activities supervised by teachers/facilitators (Coll \& Taylor, 2001). Alternative conceptions play a greater role in organic chemistry education than just creating insufficient explanations to questions. Students can construct concepts either consciously or subconsciously as explanations for the behavior, properties, or theories they have experienced. Most of these explanations are believed by students to be correct for the reason that they make sense regarding their understanding of the behavior of the world around them. Therefore, if scholars encounter new material that challenges their alternative conceptions, it is difficult for them to accept that information because it seems wrong for them (Darling-Hammond, Flook, CookHarvery, \& Osher, 2019). The pre-existing conceptions and ideas hold by students are perhaps correct but most of them are significantly dissimilar from the view point of what is accepted scientifically and tend to be modernized arbitrarily by only considering what their senses receive (Gilmore, Wilkerson, \& Hassan, 2012). The concepts constructed by students can only explain the scientific phenomena if they are not deviated from the scientific concepts (Kay \& Yiin, 2010).

Misconceptions are differences between the scientifically accepted views and students' views (Aufschnaiter \& Rogge, 2010); alternative conceptions (Adu-Gyamfi, Ampiah, \& Agyei, 2015); commonsense reasoning (Ozmen, 2004); preconceptions (Kambouri, 2015); nonscientific beliefs (Impey, Buxner, \& Antonellis, 2012); preinstructional beliefs (Treagust, Chittleborough, \& Mamiala, 2004); intuitive knowledge (Alejandra \& Keith, 2010); phenomenological primitives or p-prims (Hummer, 1996) (Ostergaard, Dahlin, \& Hugo, 2008); facets (Baporikar, 2015); or alternative frameworks (Glaze, 2018); (Muthukrishna, Carnine, Grossen, \& Miller, 1993). Irrespective of the terminology, the theme is to know that what students are familiar with influences the learning of the new concepts since they enter classrooms with deep-rooted prior knowledge or conceptions towards the natural world, a situation which can influence the understanding of their formal science experiences in the classroom (Cakir, 2008).

To ensure the meaningfully learning, the information is actively selected, ordered and constructed by learners for their better understanding since all existing knowledge and concepts, as well as the strategies of processing the information plays a dynamic role in determining the output because the new stimuli and the following generation of meaning are influenced (Darling-Hammond, Flook, Cook-Harvery, \& Osher, 2019). The problem can be approached by the student who correctly understands the concept necessitating explanations in his way and may be able to attack most puzzles properly whereas a student with a incomplete understanding of the concept will likely resort to rote learning (Omwirhiren \& Ubanwa, 2016). A report by West Africa Examination Council (WAEC) state that many students do not attempt organic chemistry questions and few who try to do 
so, answer them poorly (Donkoh, 2017); while an analysis of chemistry results in Nigeria and Kenya revealed that students failed to enroll for science-related courses in the universities and/or to qualify for the competitive job market after their secondary education (Opara, 2013). Organic chemistry sometimes confuses and seems as difficulty for novice learners if misconceptions are not addressed effectively (O'Dweyer \& Childs, 2017). The awareness of students' misconceptions in organic chemistry will contribute as a factor to improve students' academic achievement in chemistry and this will help Rwandan chemistry teachers as well as others worldwide.

\section{Concept and Source of Students' Misconceptions}

The thoughts, notions or ideas which can be regarded as the developing image of the mental process are known as concepts, it can be concrete, abstract, or even blurred (Oyserman, Elmore, \& Smith, 2012). They are also the summary of the important characteristics of a collection of ideas (Solonchak \& Pesina, 2015). A Concept can be observed in two ways, in its abstract nature and/or concrete ones. The real concepts are enhanced by students' experiences, whereas, abstract concepts are considerably challenging students to perceive (Uce \& Ceyhan, 2019). These dissimilar concepts are described by diverse researchers and some of them include naïve beliefs, misconceptions, alternative conceptions, personal constructs and persistent pitfalls, mistaken ideas, multiple private versions of science, developing conceptions, confusions, errors, misinterpretation of facts (Aufschnaiter \& Rogge, 2010).

The knowledge of students involves frequently the inter-relative system of correct and false beliefs (Dunlosky, Rawson, Marsk, Nathan, \& Willingham, 2013).
Sometimes this system is comprehensible but it is a flawed mental model which is in fight with the scientifically agreed model. Then, the end results is the unscientific explanations and predictions. Two outcomes are possible as long as the new information is introduced to students from a teacher; firstly a conceptual change would occur when a student recognizes that his/her preliminary concept was wrong, his/her inconsistent concept usually is changed to the corrected concept; secondly, the conceptual modification would not occur in case a scholar does not know that his/her initial concept was wrong, then the consequence is the assimilation of the new information into the flawed mental model (Uce \& Ceyhan, 2019).

The conceptual understanding may occurs when a learner creates the practical and scientific pathways in order to obtain the correct answers. In the development of the conceptual understanding, the representation of the terminology plays an active role and improves the ways of understanding organic chemistry because they may misunderstand the exact chemical concepts, or use terminology either non-scientifically or unpredictable with the chemical descriptions (Holme, Luxford, \& Brandriet, 2015). Defining the concepts is not enough, rather it may go by considering the relationship between concepts and how the ideas are constructed in the minds of the learners since the well organic chemistry instruction may be conducted through the achievement of conceptual knowledge (O'Dweyer \& Childs, 2017).

When educators plan for instruction, they are training learners who previously have some pre-instructional information about the planned topic. Their prior knowledge can be illogical or misinformed (Maigoro, Nansoh, Pam, \& Manji, 2017). That kind of erroneous understandings are named misconceptions or alternative conceptions 
Students' conceptual understanding of organic chemistry and classroom implications in the Rwandan perspectives: A literature review

A. Sibomana and C. Karegeya and J. Sentongo

(intuitive theories) which are not rare, they are sometimes normal parts of the education process. From everyday experiences, students develop ideas but not all those may be correct with respect to the evidence and learning in a given discipline. Besides, some ideas in different content areas are challenging to understand due to their abstract nature or are quite complex (Ajayi, 2017), (Patil, Chavan, \& Khandagale, 2019). Misconceptions might also be referred to as conceptual misunderstandings or mixed conceptions, ideas which are not in line with the reality that is believed by learners. Basically, in science, there are examples where the concepts in the mind of persons may be dissimilar from what is scientifically approved as correct and that is the great concern about misconceptions (DarlingHammond, Flook, Cook-Harvery, \& Osher, 2019; Omwirhiren \& Ubanwa, 2016).

According to (Aufschnaiter \& Rogge, 2010), misconceptions are individual creations, which are designed on what a person sees or feels and these experiences have a thoughtful effect on the willingness of students and to accept other more scientifically grounded explanations of the concepts. They also revealed that misunderstandings are mistaken beliefs or alternative views of science principles or incorrect ideas about certain science concepts. Learners do not understand the essential ideas covered in classroom teaching guidelines while even answers of some of the best learners are only right in case they use properly memorized words and when they are examined more carefully they fail to understand completely the fundamental concepts (Edomwonyi-Otu \& Avaa, 2011). Researchers reported different sources of students' scientific misconceptions including social, religion, personal experiences, gender, peer interaction, media, language, symbolic representation, textbooks, workshops, milieu (Afadil \& Diah, 2018), (Donkoh, 2017), (Soyibo, 2008), (Thompson \& Logue, 2006). Misconceptions can also be contributed by the abstract nature of the concepts, imparted by teachers or preconceived beliefs by students (Afadil \& Diah, 2018). Also, among those reasons are poor method of instruction, lack of organizational skills, improper exposure to laboratory activities, inadequate exposure to problem-solving procedures (Hanson, Sam, \& Antwi, 2012).

In addition, non-performance of practical activities in organic chemistry is caused by the lack of science equipment and related working consumables like organic solvents. It was revealed that some students deliberately avoided doing practical experiences because they deemed working with the often volatile and flammable organic solvents as dangerous and prone to catch fire (Hanson, 2017). Another cause that is taken as an underlying reason for students' indifference/misconception towards science is the non-connectivity between science subjects and one's personal life. Students' are incapable of associating science concepts with everyday life and ask about the importance of certain topics and disciplines in their lives when teachers introduce them to new lessons (Bilgin, Yurukel, \& Yigit, 2017). The limited scientific vocabulary which affects the appropriate use of the scientific expression to describe theoretical and observed events; the lack or little time for practice are also among factors that can cause misconceptions among students towards organic chemistry (Tenaw, 2015). Similarly, some students fail to correctly transfer the knowledge acquired from basic chemistry topics to the learning about organic 
chemistry (Akkuzu \& Uyulgan, 2015); and even though students might have high performance regarding explaining difficulties in organic chemistry, they have very low levels of conceptual understanding which has been related to the memorizationoriented method of education (Decocq \& Bhattacharyya, 2019).

\section{Misconceptions of Students about Organic Chemistry}

Concerning learning the new information, many students may previously have some kind of knowledge towards the topic and they also may have pre-conceptions in their minds about the new knowledgeable concept. Some take chemistry as difficult to learn and the topic of organic chemistry as one of the difficult topics (Mahdi, 2014), (Nakhleh, 1992), (O'Dweyer \& Childs, 2017). Those pre-conceptions which are also called misconceptions can be recognized as students' previous knowledge, which is embedded in a scheme of logic and explanation, although it may be mismatched with approved scientific understanding (Taufiq, Hindarto, \& Khumaedi, 2011). Frequently, misconceptions are robust and very resistant to modification, deeply rooted in everyday experience. Frequently, the new information presented by the teacher comes to conflict with the previously existing students' mental models.

Students often have an undesirable implication associated with the topic. Some behave as experts in what organic chemistry is and seem to know how to learn and perform it when many of them have little background on it, others do not even know what topics organic chemistry includes (Wasacz, 2010). There are still misconceptions about organic chemistry where it is sometimes taken as difficult to learn by secondary school students. Students' difficulties and misconceptions are most of the time about applying IUPAC rules in naming organic compounds which is at the symbolic level of learning chemical concepts, writing of the structural formulae of hydrocarbons and unsaturated hydrocarbon, distinguishing substitution and addition reactions, polymerization (Omwirhiren \& Ubanwa, 2016); differentiating aromatic compound from condensed structure formula (Topal, Oral, \& Ozden, 2007); isomerism (Sharma \& Decicco, 2018); representation and drawing of organic compounds (Treagust, Chittleborough, \& Mamiala, 2004); the properties of organic compounds (Anderson \& Bodner, 2008); Aromaticity (Topal, Oral, \& Ozden, 2007); classification of organic compounds (Adu-Gyamfi, Ampiah, \& Appiah, 2017); reaction mechanisms (Ojima, 2017); functional groups (Akkuzu \& Uyulgan, 2015).

In America, research by (McClary \& Bretz, 2012); revealed difficulties and misconceptions among undergraduate students who took organic chemistry course; their misconceptions were in the characterization of the acid/base strength of an organic compound by thinking that the stability and functional group regulate the acid/base strength of an organic compound. They faced also difficulties in understanding alkyl halide reactions, such as determining if a compound is a nucleophile or base; determining the base and nucleophile strength of a compound, the description of the stages of alkyl halide reaction, and determine the transitional reaction formed in the alkyl halide reaction. In Germany, the regular students 'misconceptions and/or difficulties was the boiling point of organic compounds (Schmidt, Kaufmann, \& Treagust, 2009). The above-mentioned consequences show the inadequate understanding of students about intermolecular forces (Cooper, Underwood, \& Williams, 2015); whereas, in Turkey, misconceptions about organic chemistry 
Students' conceptual understanding of organic chemistry and classroom implications in the Rwandan perspectives: A literature review

A. Sibomana and C. Karegeya and J. Sentongo

have been found in pre-service teachers, a factor that can influence negatively secondary school students; their misconceptions were about the alkene concept, such as naming cycloalkanes, polymerization reaction and the application of Markovnikov and anti-Markovnikov rules (ŞENDUR, 2012).

Another misconception was held by several pre-service natural sciences educators about geometric isomers (Sendur \& Toprak, 2013). It is from the use of $1,2-$ dichloroethene as an example of geometric isomer that the scholars assume that only alkene combinations comprising two halogen bonds on $\mathrm{C}=\mathrm{C}$ bonds have geometric isomer (Sharma \& Decicco, 2018). Besides, taking organic chemistry as difficulty concept in chemistry affects students in the understanding of the advanced organic chemistry conception. Organic compound's physical characteristics are taken by some students as challenging. They think that only the bond polarity be contingent on the atom electronegativity and they fail to distinguish the concepts of boiled and burned and finally accept that covalent bond would break when an organic complex boils. Besides, they could not categorize types of reactions, and they trust that a hydrogen bond includes a covalent bond (Taagepera \& Noori, 2000).

New concepts can be difficult to learn if misconceptions are not corrected among students; some of them can be detached simply although most of them are strongly held and regularly not affected by regular classroom instruction since these are something learners trust (Belachew, Barke, \& Yitbarek, 2018). Students usually have confusion and difficulty in the learning of organic chemistry due to no algorithms' problem-solving of this topic as it has an extensive new vocabulary and requires three-dimensional thinking (Wu, Krajcit, \& Soloway, 2001). Among the major complications of organic chemistry for learners is the understanding of the threedimensional nature of molecules which they have extreme difficult converting between the two-dimensional drawings used in textbooks and on boards to represent molecules and their three-dimensional structures without this understanding, to continue the course, students have to pretend they understand the three-dimensional structures (Bateman, Booth, Sirochman, \& Richardson, 2002). The difficulty encountered by undergraduate students in understanding the course prevents many of them from continuing with this career path (Horowitz, Rabin, \& Brodale, 2013).

Moreover, studies by (Bryan, 2007), (Kay \& Yiin, 2010), in Singapore revealed some students' misconceptions and learning difficulties in organic chemistry sub-topics like in the introduction to organic chemistry and hydrocarbons in some sub-topics like isomerism, reactivity of alkanes and alkenes, halogenoalkanes (alkyl halides), alkohols and esthers, and the benzene ring while in Taiwan, the challenging concepts of organic chemistry was seen in organic compounds where the $-\mathrm{OH}$ group and the phenols do not show any visible reaction with carboxylic acids since both are acids and that acids do not react with each other (Chiu, 2007); while students in some African countries saw organic chemistry as a difficulty topic to be followed in their further studies (Horowitz, Rabin, \& Brodale, 2013); (Gebrekdian, Annette, \& Lise, 2014); (Mafuniko, 2008); (Sarkodie \& Adu-Gyamfi, 2015)

\section{Diagnosing Students' Misconceptions}

The diagnosis of students' misconceptions can be done by identifying and addressing them by applying a strategy of questioning 
and listening. Different strategies can be employed to understand what learners are thinking about the topic previously in response to instruction like learning using conceptual change as a technique which texts the well-known misconceptions of students (Belachew, Barke, \& Yitbarek, 2018). These approaches comprise various forms of real type feedback which can stimulate students' participation while learning (Patil, Chavan, \& Khandagale, 2019).

Another method is typified by the strategy known as Just-in-Time teaching as an educational approach that uses feedback between the work that students do at home, in preparation for the classroom meeting and the classroom activities (Killi \& Morrison, 2015). These goals meant to improve learning in the classroom, to develop students' motivation and stimulate their previous preparation for class, to permit the teacher to fine-tune the classroom accomplishments to best meet the needs of students (Cakir, 2008). In such situation, scholars respond to various questions prior to class and the teacher uses the given answers from students to familiarize his or her teaching to their misconceptions and to what they already know in a positive way. The way of interviewing students for the purpose of producing the items that make up a concept inventory or other forms of diagnostic apparatuses is also a researchintensive approach that may be used (Stojanovska \& Petrusevski, 2017). Concept inventories can also be helpful in identifying problematic ideas that can hinder the active instruction (Bryan, 2007). For educators to well identify students' misunderstandings, it is advised to first identify their preconceptions and developing conceptions because some students' misconceptions can be generated by teachers' malpractices while in classroom such us the language of instruction, used textbooks and cultural belief, then learners may need to have their thoughts being considered at a certain level (Soyibo, 2008).

\section{Remedies of Students' Misconceptions by Effective Organic Chemistry Instruction}

The effectiveness of teaching methods refers to the students' abilities to apply learned lessons in the different contexts of life and remove their misconceptions about organic chemistry. The use of micro kits by conducting small scale organic chemistry activities have been known to enhance students' conceptions in most of the Asian countries including Thailand, Japan, Taiwan, and Indonesia (Supasorn, 2015) ; (Zakaria, Latip, \& Tantayanon, 2012); in South Africa (Hansan \& Sakyl-Hagan, 2019); in Ghana (Hanson, 2014); Ethiopia (Gebrekdian, Annette, \& Lise, 2014); and in Tanzania (Mafuniko, 2008). When it was introduced to students who had misconceptions about organic chemistry in Ghana, it was found to be a tool to enhance students' understanding and academic achievement (Hanson, 2014). Students who applied them in practical experiences made conceptual improvements as they overcame their challenges in principles that directed the study of organic chemistry (Hanson, 2017). In this way, they are involved involve in a kind of reality as they observed the causes and effects of phenomena in different variables (Darling-Hammond, Flook, CookHarvery, \& Osher, 2019). These concrete illustrations enhanced their concept formation and subsequently, academic performance. The micro activities enabled students to verbalize, discuss, and explain scientific processes, as they worked together (Sedumedi, 2017). Similarly, engaging scholars in the application of context-based learning (CBL) approach with respect to the constructivist paradigm, enhances the stimulation of students' interest and motivation as well as providing more 
Students' conceptual understanding of organic chemistry and classroom implications in the Rwandan perspectives: A literature review

A. Sibomana and C. Karegeya and J. Sentongo

interconnected content knowledge (Vos, Taconis, Jochems, \& Pilot, 2011).

The constructivist learning model is frequently associated with innovative learning strategies that encourage active learning or learning by doing. It is a theory of learning based on scientific study observation about how people learn by constructing students' own understanding and knowledge of the world by experiencing things around them and reflecting on those experiences. Some innovative learning models that have been reported to be remedies of students' misconceptions are but not limited to cooperative learning strategy due to the fact that it is an innovative approach that employs a lot of motivational procedures to make instruction relevant, students more responsible and improve students' interest and achievement in organic chemistry (Canelas, Hill, \& Novicki, 2017) (Ukpepi, Aglazor, \& Odey, 2016); peer instruction, a method of cooperative learning which is also an active learning where peers discuss ideas and share answers to questions in an in-class environment with opportunities for further interactions with their teacher, it improves students' conceptual understanding as has been observed in multiple science disciplines (Crouch \& Mazur, 2001), (Knight \& Brame, 2018); context-based learning with micro activities, a method which enables students to build concepts in basic organic chemistry in everyday experiences for life, hence improvement of students' academic achievement (Hanson, 2017).

Also, the use of ball-and-stick modes increases students' performance in naming and writing structural formulae of hydrocarbons and enhances their attitudes towards the subject (Sarkodie \& AduGyamfi, 2015); Inquiry-based learning, a method which equips students with suitable technical skills for both postgraduate research and industry. It collects much attention in scholastic practice and theory by providing opportunities to both students and teachers to dynamically engage in answering questions collaboratively (Pilcher, Riley, \& Potgieter, 2015); problem-based learning which answers various concerns regarding instructive methods, inspires students to look for new solutions to pertinent problems using accessible knowledge and resources. The process increases students' problemsolving skills and critical thinking while enhancing their creative capabilities (AlSahili \& Alobaidi, 2018).

In addition, problem-solving in organic chemistry relies more on judging trends in reactivity, developing mechanisms to predict chemical change, or justifying threedimensional relationships than mathematical calculations. Consequently, step-by-step synthesis or solving spectral data and promising mechanisms are frequently applicable in organic chemistry than in general chemistry and characterize a new way of thinking for learners (Graulich, 2015); reciprocal causation, a technique which increases students' academic performance and retention in organic chemistry (Villafane, Xu, \& Raker, 2016); computer-based learning which enables students to cope with the proposed digitalization of the organic chemistry (Olehi, Duru, Uchegbu, \& Amanze, 2018); hands-on activity-based method which has been reported to enhance students' interest in learning organic chemistry (Ajayi, 2017); guided-inquiry which improves conceptual understanding among students (Schoffstall, 2007); graphic organizers, a teaching strategy which employs instruments of representation and modelling the information in graphics or visuals form to achieve a meaningful learning (Zaini, 
Mokhtar, \& Nawawi, 2010); anchored instruction, a method of using an advance organizer based anchoring, a device of meaningful learning that may be used as an icebreaker for students to understand the abstract concept of the formation of covalent bonds in organic molecules (Adhikary, Sana, \& Chattopadhyay, 2017); and by inquiry-based learning where actions rely on the deep foundation of accurate knowledge where learners use observation, reasoning, and imagination about scientific phenomena by learning the ways of organizing knowledge within a conceptual context (Duran \& Duran, 2004).

Furthermore, the acknowledgement and revision of the misconceptions of students involves innovative teaching strategies rather than the passively learning approaches. A common method of instruction includes meta-cognition that is to boost the students' thinking about techniques of addressing a particular problem (Fisher, 2006). This technique necessitates students to express and defend their understanding. From the recognition of the authenticities of the current classroom requires the application of innovative teaching methods that provide the active participation of students and incorporate their metacognition and critical thinking; then the creation of a deep foundation of factual knowledge which enables students organizing the knowledge within a conceptual structure based on the experienced events (Cakir, 2008) (Canelas, Hill, \& Novicki, 2017). Teachers monitor the concepts changing of the students through the evaluation techniques as the training proceeds. The inquiry activities should be developed from simple concrete examples to abstract. Learners can improve their understanding through inquiry by generating, ask, and discuss challenging questions.
The application of multiple cycles of investigation that enable scholars to ask the same questions for them to understand the concept is among strategies that create students' curiosity towards the topic (Palincar, Marcum, Fitzgerald, \& Therwood, 2017). Through different approaches that apply formative assessment in education, educators find ways to help students redirecting scientific misconceptions and assisting them to reconstruct their conceptual framework (Dunlosky, Rawson, Marsk, Nathan, \& Willingham, 2013). However, deciding to create manners to help learners overcome their misunderstandings one might try employing different methods including the application of innovative teaching methods that allow learners to actively participate in the learning process and to discover more (Uce \& Ceyhan, 2019).

The process of teaching and learning organic chemistry could be structured by enabling students to overcome challenges for them to be prepared for the world of tomorrow; offering them information and helpful examples (which they are familiar with); showing them the cognitive processes that lead to conceptual generalizations and algorithms (Opara, 2013). Organic chemistry educators should try to include conceptual questions assessing students' understanding of the fundamental notions in the subject, instead of just setting questions which require only mostly recall and rote learning. They should pay exceptional attention to the identified misconceptions in the topic and address them in their instruction and stimulating learners' interaction (Michael, 2006). The way a student processes the learned information and applies it, goes hand in hand with his/her learning style (Woldeamanuel, Atagana, \& Engida, 2014).

Effectiveness of Cooperative Learning in Organic Chemistry Instruction 
Students' conceptual understanding of organic chemistry and classroom implications in the Rwandan perspectives: A literature review

A. Sibomana and C. Karegeya and J. Sentongo

Cooperative learning refers to a method of knowledge construction where learners with varying levels of skills and knowledge in small groups, work together, and share information on a given task. In this way, the learners assume full responsibility for their learning in part by peer teaching. According to (Koppenhaver \& Shrader, 2003), cooperative learning instructional strategy enhances critical thinking, social skills, and retention of information learned much longer. Besides, they give the teacher more time for supervising learners' group work and embarking on comprehension checks as well as provide a one -to one interaction among learners (Olupide \& Awokoy, 2010). It is based on this and other proven advantages associated with these methods that (Johnson, Johnson, \& Smith, 2014) suggest their inclusion in instructional planning. The development of a positive attitude towards the subject and teaching strategies is influenced by learning cooperatively where learners find working together in groups enjoyable and since they can always rely on each other for help (Amedu, 2017).

According to (Singh \& Agrawal, 2011), individuals learn in a small group with the help of each other in a cooperative learning process, it contrasts the lecture method of learning which is competitive where scholars work independently and being continually in competition with one another for scores, praise, and appreciation; such competitions do have negative effects that lead to students' low scholastic achievement in sciences, especially chemistry. Learning cooperatively is an essential tool for educating individual how to encounter the increasing of the global interdependence, the involvement of each and every learner in class; the need for creative industrialists and the important development of interpersonal interactions (Johnson \& Johnson, 2014).

Different studies described what cooperative learning effort is and what is not as follow: Learners are given task to do in group but some are not interested to work with peers believing that they will be evaluated individually (Pseudo learning group); learners are assigned to work together and agreed on the working conditions with their facilitator and the assignments are structured to be evaluated and rewarded one by one, not as the group members. Students seek each other's information but have no incentive to share what they know to group mates (Traditional classroom group); they are working in groups to complete the shared goals, pursue results that are valuable to all, discuss the material together and help one another understand it, and encourage it other to work hard. The performance of an individual is supposed to be checked regularly to ensure that all learners are contributing and learning and the outcome is the same for all learners in the group (Cooperative learning); and a group of learners that meets all the standards for being a cooperative learning group and beats all reasonable expectations. The level of commitment of the members of this kind of groups is beyond that of most cooperative learning groups. Few groups ever achieve this level of improvement (Highperformance cooperative learning group) (Johnson \& Johnson, 2014); Singh \& Agrawal, 2011; Yassim, Razak, \& Maasum, 2018).

Organic chemistry teaching and learning is enhanced by the application of cooperative learning which improves students' problemsolving, communication, leadership, and collaboration competencies among classmates and skills (Canelas, Hill, \& Novicki, 2017). The potential of the 
classroom cooperative work in the structure of learning chemical concepts and organic functions are influenced by cooperative learning instructional strategy by granting learners' interdependence in accomplishments and the teacher to ensure the contribution of all group members in learning. Considering its main features, the above-mentioned teaching technique reassures mutual learning among scholars from the articulation between activities and the study contents; even though the work is collective, there is an individual accountability for a good group performance, which can be attained through individual examinations and division of roles while working on the given tasks (Oliveira, Vailati, Luiz, Böll, \& Mendes, 2019).

\section{Some Learning Theories for the Effective Teaching and Learning Organic Chemistry Behaviorism and Cognitivist}

Behaviorism paradigm and behaviorist focuses on observable behaviors, they believe that the main purpose of education is that learners' behavior is to respond to their past and behavioral modification. They define learning as the acquisition of new behavior based on environmental conditions. For them, the classroom interaction is focused mainly on behavior modification where the information is transmitted to the learner, and this was considered as a real mode of instruction; which is rote learning. Conversely, cognitivist realized the limitations of the behaviorist theory and started focusing on the development of the brain by focusing on the two main functions which are organization and adaptation in learning (Agarkar, 2019). These two main functions are effective for both organic chemistry educators and students since organization mentions the fact that all reasoning structures are interconnected, and that any new information must be tailored into the current system. Organic chemistry is applied in our daily life and everyone seeks to facilitate his/her daily needs by simple applications, a case which is referred to adaptation as the tendency of the organism to fit with its setting in ways that encourage survival and this because learning is enhanced by assimilation and accommodation where assimilation is the process through which new information is related to existing knowledge whereas accommodation is the difference between what the child already knew and what they learn in the new experience (Lefa, 2014).

Therefore, the process of cognitive development is the result of a series of related assimilation and accommodation. In his theory, Piaget explains how, why, and when children develop and learn new concepts. Because he didn't believe in prescribing steps and procedures, as he believes learners construct their own knowledge, he instead provided a structure of reference by which educators can examine the behavior of the student and design educational milieus within which students can create their own knowledge, hence advised the application of two teaching models, inquiry training and discovery learning; educators to be aware of their actions and how to present themselves (Dobber, Zwart, Tanis, \& Oers, 2017). Thus, students' ability should be supported to regulate their own thinking and make them more effective; contents should be organized from simple to complex; concrete to abstract.

\section{Constructivism}

Constructivism seems to be the dominant way of thinking about learning in science education. Education is a requirement of life, social process of ongoing change, and transformation of the individual experience, being taken with the concept of development and it is a process of living. Activity is the 
Students' conceptual understanding of organic chemistry and classroom implications in the Rwandan perspectives: A literature review

A. Sibomana and C. Karegeya and J. Sentongo

important characteristic of the child's nature, which is articulated through his instincts, involvement, interests, and independence. They present a huge instructive potential and preliminary point of the process of education, but are not an end in itself; they need to be measured and directed toward the realization of predetermined goals (Leshkovsk \& Spavera, 2016). Effective organic chemistry teaching and learning is a product of a well-designed constructivist classroom that offer a diversity of activities to challenge students to accept individual differences and use concrete learning experiences since constructivist lessons are based on the fact that students construct their own implication; new knowledge builds on prior knowledge; a learning that is improved by social interaction and a education to be developed through authentic tasks (Cakir, 2008); (Coll \& Taylor, 2001). Various methodologies in pedagogy originate from constructivist theory. They advise that learning may be accomplished best using a hands-on method. Students acquire by experimentation, rather than by being communicated what will happen, and are left to make their own interpretations and deductions (Dagar \& Yadav, 2016); (O'Connor, 2015).

\section{Brain-Based Learning}

Brain-based learning improves students' retention since it employs instructional techniques that are designed in ways that stimulate learners to form different types of associations in science education (AlBalushi \& Al-Balushi, 2018). There has been a deliberate effort made to connect learning to students' actual lives and sensitive experience, individual histories, and experiences and this has led to fresher concepts of learning like mastery learning, experimental learning, problem-based learning, and embodied (movement education) learning. The brainteaser game in basic organic chemistry increases students' academic performance and interest; the brain also performs many functions at the same time. It can perceive wholes and parts simultaneously (Cha†, Kant, Nurul Huda Abdul Wahab§, \& Chia, 2017).

Hands-on (experiential learning) has been reported to be an effective teaching approach to organic chemistry (Hanson, 2017). This implies the brain and helps students to be more intrinsically motivated to learn, rather than just memorizing information for a short period and increase attention to critical thinking. The information absorbed by the brain to which it is directly aware and signals that lie beyond the immediate focus of attention (peripheral). The brain replies to the entire sensory setting in which teaching and communication occur (Degan, 2011). Educators select the teaching approaches that are available to fully engage the learner such as group discussions which allow students to ask questions; orient the class to the learning which is shaped by both internal process and social interactions with all sense immersed in interactive experiences; using real-life activities like visiting different manufactures which apply organic chemistry in different forms (field trip) (Arun \& Singaravelu, 2018). The more we learn from others, the more unique we become.

\section{Classroom Implication and Recommendations}

The research on students' conceptual understanding in organic chemistry has invaluable implications on chemistry teaching and learning in Rwanda and the entire world. Chemistry educators will get insight from this review and plan for organic chemistry instruction considering learners' 
prior knowledge, strategies to diagnose and address students' misconceptions, knowing areas where students have difficulties about the topic and employ innovative teaching methods that enable learners to be active in the process of teaching and learning, interact with peers, doing practical experiences that may improve their discoveries. Students should not be treated as empty vessels or blank slates; on the contrary, learning activities should be related to their prior knowledge and interests, emphasize understandable material to enhance students' productive thinking. The use of the self-explanatory textbook (conceptual textbook) containing common students' misconceptions in organic chemistry and their corresponding correct explanations can help students being aware of possible misconceptions and their corrections. It is of more importance to teachers to have

\section{References}

Adhikary, C., Sana, S., \& Chattopadhyay, K. N. (2017). Advance organiser based anchored instruction for teaching sigma $(\sigma)$ and pi $(\pi)$ bonds: an orbital overlap analogy. IJSART, 3(10).

Adu-Gyamfi, K., Ampiah, J. G., \& Agyei, D. D. (2015). High school chemistry students' alternative conceptions of $\mathrm{H} 2 \mathrm{O}, \mathrm{OH}-$, and $\mathrm{H}+$ in balancing redox reactions. International Journal of Development and Sustainability, 4(6), 744-758.

Adu-Gyamfi, K., Ampiah, J. G., \& Appiah, J. Y. (2017). Students' difficulties in IUPAC naming of organic compounds. Journal of Science and Mathematics Education, 6(2), 77-106.

Afadil, \& Diah, A. W. (2018). Effectiveness of learning materials with sciencephilosophy oriented to reduce misconception of students on chemistry. First Indonesian Communication Forum of Teacher Training and Education Faculty Leaders International sufficient knowledge of the subject content that enables them to change students' misconceptions and lead them to a brighter scientific future. For the minimization of students' misconceptions about organic chemistry, cooperative learning models such as Think-Pair-Share approach; Jigsaw approaches; Reverse Jigsaw; Reciprocal Peer Teaching approach; Student TermsAchievement Divisions (STAD); ThinkAloud Pair Problem Solving Approach (TAPPSA); Group Grid approach; Group Writing Assignment Approach; Base Group Learning; Numbered Head Together and many other different innovative teaching strategies are recommended to apply in organic chemistry instruction. There is a need for further research on instructional methods to improve students' conceptual understanding of organic chemistry and other chemistry topics.

Conference on Education 2017(ICE 2017). 174. Atlantis Press. doi:10.2991/ice-17.2018.43

Agarkar, S. C. (2019). Influence of learning theories on science education. Resonance, 24, 847-859. doi:https://doi.org/10.1007/s12045019-0848-7

Ajayi, O. V. (2017). Effect of hands-on activitybased method on interest os senior secondary students in organic chemistry. Scholarly Journal of education, 6(1), 1-5.

Akkuzu, N., \& Uyulgan, M. A. (2015). An epistemological inquiry into organic chemistry education: exploration of undergraduate students' conceptual understanding of functional groups. Chemistry Education Research and Practice. doi:10.10.1039/c5rp00128e

Al-Balushi, K. A., \& Al-Balushi, S. M. (2018). Effectiveness of brain-based learning for grade eight students' direct and postponed retention in science. 
Students' conceptual understanding of organic chemistry and classroom implications in the Rwandan perspectives: A literature review

A. Sibomana and C. Karegeya and J. Sentongo

International Journal of Instruction, $11(3), 525-538$.

Alejandra, F., \& Keith, T. (2010). Intuitive thinking and chemistry learning . Educacion Quimica, 21, 111-117.

Al-Sahili, F. G., \& Alobaidi, A. H. (2018). Problem-based learning (PBL) in organic chemistry. IJMS, 1(2), 64-70.

Amedu, O. I. (2017). Attitude of students towards cooperative learning in some selected secondary schools in Nasarawa state. Journal of Educational and Practice, 8(10).

Anderson, T. L., \& Bodner, G. M. (2008). What can we do about 'Parker'? A case study of a good student who didn't 'get' organic chemistry. Chemistry Education Research and Practice, 9, 93-101. doi:10.1039/b806223b

Arun, A., \& Singaravelu, G. (2018). Brain based teaching approach in science - a new paradigm of teaching. Review of Research, 7(11).

Aufschnaiter, C. V., \& Rogge, C. (2010). Misconceptions or missing conceptions? Eurasia Journal of Mathematics, Science \& Technology Education, 6(1), 3-18.

Baporikar, N. (2015). Quality facets in educational process for enhanced knowledge creation. International Journal of Service Science, Management, Engineering, and Technology, 6(4), 1-15. doi:10.4018/IJSSMET.2015100101

Bateman, R. C., Booth, D., Sirochman, R., \& Richardson, J. R. (2002). Teaching and assessing three-dimentional molecular literacy in undergraduate biochemistry. Journal of Chemical Education, 79(5).

Belachew, W., Barke, H.-D., \& Yitbarek, S. (2018). Effects of conceptual change instructional approach on achievement of pre-service chemistry teachers in aliphatic hydrocarbon concepts. African Journal of Chemical Education, 8(2).

Bilgin, A. K., Yurukel, F. N., \& Yigit, N. (2017). The effect of a developed react strategy on the conceptual understanding of students: "particulate nature of matter". Journal of Turkish Science Education, 14(2), 65-81.

Bryan, L. C. (2007). Identifying students' misconceptions in "A-level" organic chemistry. Journal of Chemical Education. doi:10.1.570.6309\&rep=rep1\&type $=$ pd $\mathrm{f}$

Cakir, M. (2008). Constructivist approaches to learning in science and their implications for science pedagogy: a literature review. International Journal of Environmental \& Science Education, 3(4), 193-206.

Canelas, D. A., Hill, J. L., \& Novicki, A. (2017). Cooperative learning in organic chemistry increases students assessment of learning gains in key transferable skills. Chemistry Education Research and Practice, 18, 441-456. doi:10.1039/c7rp00014f

Chat, J., Kant, S.-Y., Nurul Huda Abdul Wahab§, A. N., \& Chia, P. W. (2017). Incorporation of brainteaser game in basic organic chemistry course to enhance students' attitude and academic achievement. Journal of the Korean Chemical Society, 61(4). Retrieved from https://doi.org/10.5012/jkcs.2017.61.4. 218

Chiu, M.-H. (2007). A national survey of students' conceptions of chemistry in Taiwan. International Journal of Science Education, 29(4), 421-452. doi:10.1080/09500690601072964

Coll, R. K., \& Taylor, T. G. (2001). Using constructivism to inform tertiary chemistry peadagogy. Chemistry 
Education: Research and Practice in Europe, 2(3), 215-226.

Cooper, M., Underwood, S. M., \& Williams, L. C. (2015). Student understanding of intermolecular forces: a multimodal study. Journal of Chemical Education, 92(8). doi:10.102/acs.jchemed.5b00169

Crouch, C. H., \& Mazur, E. (2001). Peer instruction: ten years of experience and results. American Journal of Physics, 69(970). doi:10.1119/1.1374249

Dagar, V., \& Yadav, A. (2016). Constructivism: a paradigm for teaching and learning. Arts and Social Sciences Journal, 7(4). doi:10.4172/2151-6200.1000200

Darling-Hammond, L., Flook, L., CookHarvery, C., \& Osher, B. B. (2019). Implication for educational practice of the science of learning and development. Applied developmental Science.

doi:10.1080/10888691.2018.1537791

Decocq, V., \& Bhattacharyya, G. (2019). TMI (too much information)! effects of given information on organic chemistry students' approaches to solving mechanism tasks. Chemistry Education Research and Practice, 20, 213-228. doi:10.1039/c8rp00214b

Degan, R. J. (2011). Brain-based learning: the neurological findings about the human brain that every teacher should know to be effective. Paris: International School of Management.

Dobber, M., Zwart, R., Tanis, m., \& Oers, B. V. (2017). Literature review: the role of the teacher in inquiry-based. Educational Research Review, 22, 194-214. doi:10.1016/j.edurev.2017.09.002

Donkoh, S. (2017). Very difficult senior high school organic chemistry topics: students and teachers perceptions. International Journal of Creative Research Thoughts, 5(4).

Dunlosky, J., Rawson, K. A., Marsk, E. J., Nathan, M. J., \& Willingham, D. T.
(2013). Improving students' learning with effective learning techniques: promising directions from cognitive and educational psychology. Psychological Science in the Public Interest, 1(4), 458.

Duran, L. B., \& Duran, E. (2004). The 5E instructional model: a learning cycle approach for inquiry-based science teaching. The Science Education Review, 3(2).

Edomwonyi-Otu, L., \& Avaa, A. (2011). The challenge of effective teaching of chemistry: a case study. Leonardo Electronic Journal of Practices and Technologies(18), 1-8.

Fisher, R. (2006). Thinking about thinking: developing metacognition in. Early Child Development and Care, 141(1), 115. doi:10.1080/0300443981410101

Gebrekdian, T., Annette, L., \& Lise, K. (2014). Small-scale chemistry for a hands-on approach to chemistry practical work in secondary schools: experiences from Ethiopa. African Journal of Chemical Education, 4, 48-94.

Gilmore, M. W., Wilkerson, D., \& Hassan, R. (2012). The effect of preconceived notions and the lack of fundamental skills while taking general chemistry. Atlas Journal of Science Education, 2(1), 70-76. doi:10.5147/aje.2012.0098

Glaze, A. L. (2018). Teaching and learning science in the 21 st century: challenging critical assumptions in post-secondary science. Education Sciences, 8(12). doi:10.3390/educsci8010012

Graulich, N. (2015). The tip of the iceberg in organic chemistry classes: how do students deal with the invisible? Chemistry Education research and Practice, 16, 9-21. doi:10.1039/c4rp00165f

Hansan, R., \& Sakyl-Hagan, N. (2019). Understanding teacher trainees' reasoning patterns about the formation and description of chemical compounds. 
Students' conceptual understanding of organic chemistry and classroom implications in the Rwandan perspectives: A literature review

A. Sibomana and C. Karegeya and J. Sentongo

Science Education International, 30(2), 105-115. doi:10.33828/sei.v.30i2.4

Hanson, R. (2014). Using small scale chemistry equipment for the study of some organic chemistry topics-a case study in an undegraduate class in Ghana. Journal of Educational Practice, 5(18).

Hanson, R. (2017). Enhancing students' performance in organic chemistry through context-based learning and micro activities- a case study. European Journal of Research and Reflection in Educational Sciences, 5(6).

Hanson, R., Sam, A., \& Antwi, V. (2012). Misconceptions of undergraduate chemistry teachers about hybridisation. African Journal of Educational Studies in Mathematics and Sciences, 10.

Holme, T. A., Luxford, C. J., \& Brandriet, A. (2015). Defining conceptual understanding in general chemistry . Journal of chemical education. doi:10.1021/acs.jchemed.5b00218

Horowitz, G., Rabin, L. A., \& Brodale, D. L. (2013). Improving student performance in organic chemistry: help seeking behaviors and prior chemistry aptitude. Journal of the scholarship of teaching and learning, 13(3), 120-133.

Hummer, D. (1996). Misconceptions or P-Prims: how may alternative perspectives of cognitive structure influence instructional perceptions and intentions? Journal of the Learning Sciences, 5(2), 97-127.

Impey, C., Buxner, S., \& Antonellis, J. (2012). Non-scientific beliefs among undergraduate students. Astronomy Education Review,

11. doi:10.3847/AER2012016

Johnson, D. W., \& Johnson, R. T. (2014). Cooperative Learning in 21st Century. Anales de Psicologia, 30(3), 841-851. Retrieved

from http://dx.doi.org/10.6018/analesps.30.3. 201241

Johnson, D. W., Johnson, R. T., \& Smith, K. A. (2014). Cooperative learning: improving university instruction by basing practice on validated theory. Journal on Excellence in College Teaching, 25(3\&4), 85-118.

Kambouri, M. (2015). Investigating early years teachers' understanding and response to children's preconceptions. European Early Childhood Education Research Journal. doi:10.1080/1350293X.2014.970857

Kay, C. C., \& Yiin, H. K. (2010). Misconceptions in the teaching of chemistry in secondary schools in singapore \& malaysia. Proceedings of the Sunway Academic Conference 2010/1. Sunway College Johor Bahru.

Killi, S., \& Morrison, A. (2015). Just-in-time Teaching, Just-in-need Learning: Designing. Universal Journal of Educational Research, 3(10), 742-750. doi:10.13189/ujer.2015.031013

Knight, J. K., \& Brame, C. J. (2018). Peer instruction. $\mathrm{CBE}$ Life Science Education, 17, 1-4. doi:10.1187/cbe.1802-0025

Koppenhaver, G. D., \& Shrader, C. B. (2003). Structuring the classroom for performance: cooperative learning with instructor-assigned teams. Decision Sciences Journal of Innovative Education, 1(1).

Lefa, B. (2014). The Piaget theory of cognitive development: an educational implications. Educational Psychology, $1(1), 9$.

Leshkovsk, E. A., \& Spavera, S. M. (2016). John Dewey's educational theory and educational implications of Howard Gardner's multiple intelligences theory. (IJCRSEE) International Journal of Cognitive Research in Science, 
Engineering and Education, 4(2). doi:10.5937/IJCRSEE1602057A

Mafuniko, F. M. (2008). The potential of microscale chemistry experimentation in enhancing teaching and learning of secondary chemistry: experiences from Tanzania classrooms. NUE Journal of International Educational Cooperation, 3, 63-79.

Mahaffy, P. (2004). The future shape of chemistry education. Chemistry Education Research and Practice, 5(3), 229-245.

Mahdi, J. G. (2014). Students attitudes chemistry: An examination of choices and preferences. American Journal of Educational Research, 2(6), 351-356. doi:10.12691/education-2-6-3

Maigoro, I. L., Nansoh, M. D., Pam, E. D., \& Manji, W. M. (2017). The relationship between types of misconceptions and achievement in genetics among senior secondary school biology students in Jos North LGA of plateau state. International Journal of Quantitative and Qualitative Research Methods, 5(3), 126.

McClary, L. M., \& Bretz, S. L. (2012). Development and assessment of a diagnostic tool to identify organic chemistry students' alternative conceptions related to acid strength. International Journal of Science Education, 34(15), 2317-2341. doi:10.1080/09500693.2012.684433

Michael, J. (2006). Where's the evidence that active learning works? Advance in Physiology Education, 30, 159-167. doi:10.1152/advan.00053.2006

Muthukrishna, N., carnine, D., Grossen, B., \& Miller, S. (1993). Children's alternative frameworks: should they be directlyaddressed in science instruction? Journal of research in Science Teaching, $30(3)$, doi:10.1002/tea.36603300303
Nakhleh, M. B. (1992). Why some students don't learn chemistry? Journal of Chemical Education, 69(3), 191-196.

O'Connor, C. (2015). A practice-led approach to aligning learning theories with learning and teaching strategies in third level chemistry education. Irish Journal of academic Practice, 4(1). doi:10.21427/D7B42F

O'Dweyer, A., \& Childs, P. E. (2017). Who says organic chemistry is difficult? exploring perspectives and perceptions. Eurasia Journal of Mathematics Science and Technology Education, 13(7), 35993620 . doi:10.12973/eurasia.2017.00748a

Ojima, I. (2017). Great challenges in organic chemistry. Frontiers in Chemistry, 5(52). doi:10.3389/fchem.2017.00052

Olehi, L. C., Duru, C. E., Uchegbu, R. I., \& Amanze, K. O. (2018). Improving interest and performance in organic chemistry pedagogy by incooperating animations. American Journal of Educational Research, 6(3), 277-280. doi:10.12691/education-6-3-15

Oliveira, B. R., Vailati, A. L., Luiz, E., Böll, F. G., \& Mendes, S. R. (2019). Jigsaw: using cooperative learning in teaching organic functions. Journal of Chemical Education, 96(7), 1515-1518. doi:10.1021/acs.jchemed.8b00765

Olupide, D., \& Awokoy, J. O. (2010). Effect of cooperative learning teaching strategy on the reduction of students' anxiety for learning chemistry. Journal of Turkish Science Education, 7(1), 30-36.

Omwirhiren, E. M., \& Ubanwa, A. O. (2016). An analysis of misconception in organic chemistry among selected senior secondary school students in zaria local government area of kaduna state, Nigeria. International Journal od Education and research, 4(7), 247-266.

Opara, M. F. (2013). Application of the learning theories in teaching chemistry: implication for global competitiveness. 
Students' conceptual understanding of organic chemistry and classroom implications in the Rwandan perspectives: A literature review

A. Sibomana and C. Karegeya and J. Sentongo

International Journal of Scientific \& Engineering Research, 4(10).

Ostergaard, E., Dahlin, B., \& hugo, A. (2008). Doing phenomenology in science education: a research review. Studies in Science Education, 44(2), 93-121. doi:DOI: 10.1080/03057260802264081

Oyserman, D., Elmore, K., \& Smith, G. (2012). Self, self-concept, and identity. J. Tangney and M. Leary (Eds). The Handbook of Self and Identity, 2nd Edition. New York, NY: Guilford Press.

Ozmen, H. (2004). Some student misconceptions in chemistry: a literature review of chemical bonding. Journal of Science Education and Technology, 13(2).

Palincar, A. S., Marcum, M. B., Fitzgerald, M., \& Therwood, c.-A. (2017). Braiding teacher practice and class-wide dialogue: an historical inquiry across three sociocultural interventions. International Journal of educational research.

doi:10.1080/0300443981410101

Patil, S. J., Chavan, R. L., \& Khandagale, V. S. (2019). Identification of misconceptions in science: tools, techniques \& skills for teachers. Aarhat Multidisciplinary International Education Research Journal (AMIERJ), VIII(II).

Pilcher, L. A., Riley, D. L., \& Potgieter, K. C. (2015). An inquiry-based practical curriculum for organic chemistry as preparation for industry and postgraduate research. South African Journal of Chemistry, 68, 236-244.

Roy, S. (2016). Chemistry in our daily life: preliminary information. International Journal of Home Science, 2(3), 361-366.

Sarkodie, P. A., \& Adu-Gyamfi, K. (2015). Improving students' performance in naming and writing structural formulae of hydrocarbons using the ball-and-stick models. Chemistry: Bulgarian Journal of Science Education, 24(2), 203-2019.

Schmidt, H.-J., Kaufmann, B., \& Treagust, D. F. (2009). Students' understanding of boiling points and intermolecular forces. Chemistry Education Research and Practice, $\quad 10, \quad 265-272$. doi: $10.1039 / \mathrm{b} 920829 \mathrm{c}$

Schoffstall, A. M. (2007). Incorporating guidedinquiry learning into the organic chemistry laboratory. Journal of Chemical Education, 84(5). doi:10.1021/ed084p848

Sedumedi, T. D. (2017). Practical work activities as a method of assessing learning in chemistry teaching. Eurasia Journal of Mathematics Science and Technology Education, 13(6), 1765-1784. doi:10.12973/eurasia.2017.00697a

ŞENDUR, G. (2012). Prospective science teachers' misconceptions in organic chemistry: the role of alkenes. Journal of Turkish Science Education, 9(3), 160185.

Sendur, G., \& Toprak, M. (2013). The role of conceptual change texts to improve students' understanding of alkenes. Chemistry Education Research and Practice, 14, 431-449. doi:10.1039/c3rp00019b

Sharma, A. K., \& Decicco, R. C. (2018). Discovering Isomerism: a guidedinquiry computational exercise for undergraduate organic chemistry. Chemistry Educator, 23, 39-41. doi:10.1333/s00897182784a

Singh, Y. P., \& Agrawal, A. (2011). Introduction to co-operative learning. Indian Streams Research Journal, 1(2).

Solonchak, T., \& Pesina, S. (2015). Concept and its structure. 2nd GLOBAL CONFERENCE on LINGUISTICS and FOREIGN LANGUAGE TEACHING, LINELT-2014, Dubai - United Arab Emirates, December 11 - 13, 2014. 192, 
pp. 352-358. Procedia-Social and Behavioral Sciences.

Soyibo, K. (2008). A review of some sources of students' misconceptions in Biology. Singapore Journal of Education, 15(2), 1-11. doi:10.1080/02188799508548576

Stojanovska, M., \& Petrusevski, V. M. (2017). Investigating the presence of misconceptions of 8th grade students through multiple-choice questions at national chemistry competition tests. Macedonian Journal of Chemistry and Chemical Engineering, 36(2), 279-284. doi:10.20450/mjcce.2017.1257

Supasorn, S. (2015). Grade 12 students' conceptual understanding and mental models of galvanic cells before and after learning by using small-scale experiments in conjunction with a model kit. Chemistry Education Research and Practice, 16, 393-407. doi:10.1039/c4rp00247d

Taagepera, M., \& Noori, S. (2000). Mapping students' thinking patterns in learning organic chemistry by the use of knowledge space theory. Journal of Science Education, 77(9). doi:10.1021/ed077p1224

Taufiq, M., Hindarto, N., \& Khumaedi, D. (2011). Student's science misconceptions concerning the state changes of water and their remediation using three different learning models in elementary school. Jurnal Pendidikan Fisika Indonesia, 7, 74-79.

Tenaw, Y. A. (2015). Effective strategies for teaching chemistry. International Journal of Education Research and Reviews, 3(3), 078-084.

Thompson, F., \& Logue, S. (2006). An exploration of common student misconceptions in science. International Education Journal, 7(4), 553-559.

Topal, G., Oral, B., \& Ozden, M. (2007). University and secondary school students' misconceptions about the concept of "Aromaticity" in organic chemistry. International Journal of Environmental \& Science Education, 2(4), 135-143.

Treagust, D. F., Chittleborough, G. D., \& Mamiala, T. L. (2004). Students' understanding of the descriptive and predictive nature of teaching models in organic chemistry. Research in Science Education, 34, 1-20.

Uce, M., \& Ceyhan, I. (2019). Misconception in chemistry education and practices to eliminate them: literature analysis. Journal of Education and Training Studies, $7(3)$. doi:10.11114/jets.v7i3.3990

Ukpepi, B. U., Aglazor, G. N., \& Odey, C. O. (2016). Cooperative learning strategy as tool for classroom management. Advances in Multidisciplinary \& Scientific Research Journal, 2(2), 67-76.

Villafane, S. M., Xu, X., \& Raker, J. R. (2016). Self-efficacy and academic performance in first semester organic chemistry: testing a model of reciprocal causation. Chemistry Education Research and Practice. doi:10.1039/c6rp00119j

Vos, M. A., Taconis, R., Jochems, W. M., \& Pilot, A. (2011). Classroom implementation of context-based chemistry education by teachers: the relation between experiences of teachers and the design of materials. International Journal of Science Education, 33(10), 1407-1432. Retrieved from http://dx.doi.org/10.1080/09500693.20 10.511659

Wasacz, J. T. (2010). Organic chemistry preconceptions and their correlation to student success. Greeley, Colorado: University of Nothern Colorado.

Woldeamanuel, M. M., Atagana, H., \& Engida, T. (2014). What makes chemistry difficult? AJCE, Special Issue (Part I), $4(2)$.

Wu, H.-K., Krajcit, J. S., \& Soloway, E. (2001). Promoting understanding of chemical 
Students' conceptual understanding of organic chemistry and classroom implications in the Rwandan perspectives: A literature review

A. Sibomana and C. Karegeya and J. Sentongo

representations: students' use of visualization tool in the classroom. Journal of Research in Science Teaching, 38(7), 821-842.

Yassim, A. A., Razak, N. A., \& Maasum, T. N. (2018). Cooperative learning: general and theoretical background. Advances in Social Sciences Research Journal, $5(8)$, 642-654. doi:10.14738/assrj.58.5116

Zaini, S. H., Mokhtar, S. Z., \& Nawawi, M. (2010). The effect of graphic organizers on students' learning in school. Malaysia Journal of Educational Technology, $10(1), 17-23$.

Zakaria, Z., Latip, J., \& Tantayanon, S. (2012). Organic chemistry practices for undergraduates using a small lab kit. Procedia-Social and Behavioral sciences, 59, 508-514. doi:10.1016/j.sbspro.2012.09.307 